\title{
Physiological response of soybean (Glycine max) as influenced by integrated nutrient management practices
}

\author{
*VISHAKHA B. POHARE, D.W. THAWAL and A.B. KAMBLE \\ Department of Agronomy, Mahatma Phule Krishi Vidyapeeth, Rahuri, Dist. Ahmednagar (MS) 413722 \\ *Corresponding author E-mail:vishakhapohare89@gmail.com
}

\begin{abstract}
Attempt has been made to study the physiological response of soybean in terms of photosynthetic rate, $\mathrm{CO}_{2}$ concentration, stomatal conductance, transpiration rate, stomatal resistance, leaf temperature and absorbed photosynthetically active radiation as influenced by integrated nutrient management practices. The experiment on soybean crop was conducted at Rahuri, Dist. Ahmednagar (MS) during Kharif season of 2014-15 and 2015-16 with treatments comprising of different doses of $\mathrm{N}$ supplied through FYM, vermicompost and neem cake.Results indicated that the photosynthetic rate, stomatal conductance, transpiration rate and absorbed photosynthetically active radiation varied significantly due to treatments as well as with stage of the crop. These parameters were highest under chemical fertilizer treatment but at par with treatments having 50 per cent $\mathrm{N}$ through FYM and VC. The lowest values were observed in treatments having neem cakes application. Among the three dates of observation, these parameters were highest at 56 DAS. Leaf temperature was not affected by the treatments.
\end{abstract}

Keywords : Soybean, photosynthetic rate, $\mathrm{CO}_{2}$ concentration, stomatal conductance, transpiration rate, stomatal resistance.

Among the oilseed crops grown in India, soybean is an important pulse and occupied fourth place in edible oil contributing 43 per cent to the total oilseeds and 25 per cent to the total oil production in the country.Maharashtra and Madhya Pradesh together contribute to 89 per cent of the total soybean production in India.

Photosynthetic rate, $\mathrm{CO}_{2}$ concentration, stomatal conductance, transpiration rate, stomatal resistance, leaf temperature, absorbed photosynthetically active radiation may vary due to meteorological conditions (Rodrigues-dasDores and Casali, 2007). During the crop growth period, the water stress causes closing of stomata, reducing the intensity of gas exchange and dissipation of thermal energy in plants. The photosynthetically active radiations modify the transpiration and stomatal resistance, which cause variation on plant metabolic activity. As elevated $\mathrm{CO}_{2}$ generally decreases stomatal conductance, it could protect the plant from drought by conserving soil moisture as well as slowing the decrease of leaf water potential under conditions of limited water or high vapour pressure deficit (Allen et al., 1998;2003). Singh and Hundal (2004) studied the PAR interception and canopy temperature of soybean under different sowing environment and irrigation levels. Bhagat et al. (2017) evaluated the effect of reduced PAR and moisture stress on soybean cultivars. Considering the above points, the present experiment was carried out in order to understand and relate the plant physiological performance under different environmental condition with integrated nutrient management practices.

\section{MATERIALS AND METHODS}

A field experiment was carried out at Post Graduate Institute Research Farm, Central Campus, Mahatma Phule Krishi Vidyapeeth, Rahuri, Ahmednagar(MS) during Kharif 2014-15 and 2015-16. The experiment was laid out in simple randomized block design with three replications. The treatments were applied to kharif soybean comprised of five sources viz., $\mathrm{T}_{1}-100 \%$ recommended dose of fertilizer (RDF), $\mathrm{T}_{2}-50 \%$ recommended dose of nitrogen (RDN) through chemical fertilizer $(\mathrm{CF})+50 \%$ recommended dose of nitrogen (RDN) through farmyard manure (FYM), $\mathrm{T}_{3}-50$ $\%$ recommended dose of nitrogen (RDN) through chemical fertilizer (CF) $+50 \%$ recommended dose of nitrogen (RDN) through vermicompost $(\mathrm{VC}), \mathrm{T}_{4}-50 \%$ recommended dose of nitrogen $(\mathrm{RDN})$ through chemical fertilizer $(\mathrm{CF})+50 \%$ recommended dose of nitrogen $(\mathrm{RDN})$ through neem cake (NC), $\mathrm{T}_{5}-25 \%$ recommended dose of nitrogen (RDN) through chemical fertilizers $(\mathrm{CF})+25 \%$ recommended dose of nitrogen (RDN) through farmyard manure (FYM) $+25 \%$ recommended dose of nitrogen (RDN) through vermicompost $(\mathrm{VC})+25 \%$ recommended dose of nitrogen 
Table 1: Periodical photosynthetic rate, $\mathrm{CO}_{2}$ concentration and absorbed PAR in soybean as influenced by different treatments (2014 and 2015)

\begin{tabular}{|c|c|c|c|c|c|c|c|c|c|}
\hline \multirow[t]{2}{*}{ Treatments } & \multicolumn{3}{|c|}{$\begin{array}{l}\text { Photosynthetic rate } \\
\left(\mu \text { mole } \mathrm{CO}_{2} \mathrm{~m}^{-2} \mathrm{~s}^{-1}\right)\end{array}$} & \multicolumn{3}{|c|}{$\begin{array}{l}\mathrm{CO}_{2} \text { concentration } \\
\left(\mu \text { mole } \mathrm{CO}_{2} \mathrm{~m}^{-2} \mathrm{~s}^{-1}\right)\end{array}$} & \multicolumn{3}{|c|}{$\begin{array}{l}\text { Absorbed photosynthetically } \\
\text { active radiation }\left(\mu \mathrm{mol} \mathrm{m} \mathrm{m}^{-2} \mathrm{~s}^{-1}\right)\end{array}$} \\
\hline & $28 \mathrm{DAS}$ & $56 \mathrm{DAS}$ & $84 \mathrm{DAS}$ & $28 \mathrm{DAS}$ & $56 \mathrm{DAS}$ & $84 \mathrm{DAS}$ & $28 \mathrm{DAS}$ & $56 \mathrm{DAS}$ & $84 \mathrm{DAS}$ \\
\hline $\mathrm{T} 1: 100 \% \mathrm{RDF}$ & 12.5 & 17.5 & 9.3 & 376 & 382 & 391 & 800 & 1100 & 629 \\
\hline $\begin{array}{l}\text { T2: } 50 \% \text { RDN through CF } \\
+50 \% \text { RDN through FYM }\end{array}$ & 11.9 & 16.6 & 8.8 & 364 & 373 & 374 & 762 & 1063 & 598 \\
\hline $\begin{array}{l}\mathrm{T} 4: 50 \% \mathrm{RDN} \text { through } \mathrm{CF} \\
+50 \% \mathrm{RDN} \text { through } \mathrm{NC}\end{array}$ & 11.5 & 16.1 & 8.5 & 353 & 361 & 362 & 738 & 1032 & 580 \\
\hline $\begin{array}{l}\text { T5:25\% RDN through CF } \\
+25 \% \text { RDN through FYM } \\
+25 \% \text { RDN through VC } \\
+25 \% \text { RDN through } \mathrm{NC}\end{array}$ & 11.3 & 15.8 & 8.3 & 345 & 352 & 356 & 728 & 1017 & 571 \\
\hline SEm + & 0.07 & 0.15 & 0.07 & 5.4 & 5.6 & 4.4 & 7.6 & 11.9 & 6.7 \\
\hline $\mathrm{CD}$ at $0.05 \%$ & 0.24 & 0.49 & 0.23 & 18.0 & 18.6 & 14.7 & 25.3 & 39.3 & 22.2 \\
\hline
\end{tabular}

Table 2: Periodical stomatal conductance and stomatal resistance in soybean as influenced by different treatments (2014 and 2015)

\begin{tabular}{|c|c|c|c|c|c|c|}
\hline \multirow[t]{2}{*}{ Treatments } & \multicolumn{3}{|c|}{$\begin{array}{l}\text { Stomatal conductance } \\
\qquad\left(\mathrm{m} \mathrm{mol} \mathrm{m}^{-2} \mathrm{~s}^{-1}\right)\end{array}$} & \multicolumn{3}{|c|}{$\begin{array}{l}\text { Stomatal resistance } \\
\qquad\left(\mu \text { mole } \mathrm{m}^{-2} \mathrm{~s}^{-1}\right)\end{array}$} \\
\hline & $28 \mathrm{DAS}$ & $56 \mathrm{DAS}$ & $84 \mathrm{DAS}$ & $28 \mathrm{DAS}$ & $56 \mathrm{DAS}$ & $84 \mathrm{DAS}$ \\
\hline $\mathrm{T} 1: 100 \% \mathrm{RDF}$ & 0.27 & 0.42 & 0.17 & 3.47 & 2.16 & 5.39 \\
\hline $\begin{array}{l}\text { T2: } 50 \% \text { RDN through CF }+50 \% \\
\text { RDN through FYM }\end{array}$ & 0.25 & 0.4 & 0.16 & 3.87 & 2.43 & 5.98 \\
\hline $\begin{array}{l}\text { T3:50 \% RDN through } \mathrm{CF}+50 \% \\
\text { RDN through VC }\end{array}$ & 0.25 & 0.41 & 0.16 & 3.58 & 2.24 & 5.55 \\
\hline $\begin{array}{l}\mathrm{T} 4: 50 \% \mathrm{RDN} \text { through } \mathrm{CF}+50 \% \\
\mathrm{RDN} \text { through NC }\end{array}$ & 0.24 & 0.39 & 0.15 & 3.95 & 2.47 & 6.1 \\
\hline $\begin{array}{l}\text { T5:25\% RDN through CF }+25 \% \\
\text { RDN through FYM }+25 \% \text { RDN } \\
\text { through VC }+25 \% \text { RDN through NC }\end{array}$ & 0.23 & 0.39 & 0.14 & 4.14 & 2.59 & 6.38 \\
\hline $\mathrm{SEm}+$ & 0.003 & 0.003 & 0.002 & 0.05 & 0.02 & 0.07 \\
\hline $\mathrm{CD}$ at $0.05 \%$ & 0.009 & 0.009 & 0.007 & 0.17 & 0.05 & 0.22 \\
\hline
\end{tabular}

(RDN) through neem cake (NC). The micrometeorological observations viz., air temperature, leaf temperature and physiological parameters viz., rate of photosynthesis, stomatal conductance and transpiration were measured with the help of portable Infra Red Gas Analyzer (IRGA) Li-Cor make photosynthesis system: LI-COR 6400(Li-Cor, Lincoln, NE, USA) at an interval of 28 days after sowing (DAS).

\section{RESULTS AND DISCUSSION}

\section{Photosynthetic rate ( $\left.\mu \mathrm{mol} \mathrm{CO}_{2} \mathrm{~m}^{-2} \mathrm{~s}^{-1}\right)$}

The photosynthetic rate of soybean at 28, 56 and 84 days after sowing (DAS) was significantly influenced due to different nutrient sources (Table 1).Among the three dates of observations the mean values of photosynthetic rate was 
Table 3:Transpiration rate and leaf temperature in soybean as influenced by different treatments (2014 and 2015)

\begin{tabular}{|c|c|c|c|c|c|c|}
\hline \multirow[t]{2}{*}{ Treatments } & \multicolumn{3}{|c|}{ 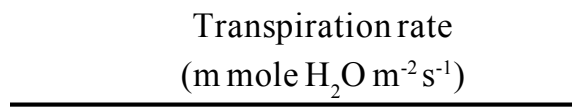 } & \multicolumn{3}{|c|}{$\begin{array}{c}\text { Leaf temperature } \\
\left({ }^{\circ} \mathrm{C}\right)\end{array}$} \\
\hline & $28 \mathrm{DAS}$ & 56 DAS & 84 DAS & $28 \mathrm{DAS}$ & $56 \mathrm{DAS}$ & $84 \mathrm{DAS}$ \\
\hline $\mathrm{T} 1: 100 \% \mathrm{RDF}$ & 3.52 & 7.67 & 4.4 & 28.6 & 29.3 & 27.8 \\
\hline $\begin{array}{l}\text { T2: } 50 \% \text { RDN through CF }+ \\
50 \% \text { RDN through FYM }\end{array}$ & 3.34 & 7.3 & 4.19 & 28.8 & 29.5 & 27.9 \\
\hline $\begin{array}{l}\mathrm{T} 3: 50 \% \mathrm{RDN} \text { through } \mathrm{CF}+ \\
50 \% \mathrm{RDN} \text { through VC }\end{array}$ & 3.42 & 7.46 & 4.28 & 28.8 & 29.4 & 27.9 \\
\hline $\begin{array}{l}\text { T4:50\% RDN through CF }+ \\
50 \% \text { RDN through NC }\end{array}$ & 3.24 & 7.08 & 4.06 & 29.3 & 30 & 28.4 \\
\hline $\begin{array}{l}\text { T5:25\% RDN through CF }+25 \% \\
\text { RDN through FYM }+25 \% \text { RDN } \\
\text { through } \mathrm{VC}+25 \% \text { RDN through NC }\end{array}$ & 3.19 & 6.98 & 4 & 29.6 & 30.2 & 28.6 \\
\hline $\mathrm{SEm}+$ & 0.02 & 0.07 & 0.06 & 0.24 & 0.29 & 0.26 \\
\hline $\mathrm{CD}$ at $0.05 \%$ & 0.08 & 0.22 & 0.2 & $\mathrm{~N} / \mathrm{A}$ & $\mathrm{N} / \mathrm{A}$ & N/A \\
\hline
\end{tabular}

maximum (15.8 and $\left.17.5 \mu \mathrm{mol} \mathrm{CO}_{2} \mathrm{~m}^{-2} \mathrm{~s}^{-1}\right)$ at $56 \mathrm{DAS}$ under different treatments and was minimum ( 8.3 to $9.3 \mu \mathrm{mol} \mathrm{CO}_{2}$ $\mathrm{m}^{-2} \mathrm{~s}^{-1}$ ) at 84 DAS. Application of $100 \% \mathrm{RDF}$ through CF found significantly higher photosynthetic rate of soybean than rest of the treatments at all the dates of observations.

\section{$\mathrm{CO}_{2}$ concentration $\left(\mu \mathrm{mol} \mathrm{CO}_{2} \mathrm{~m}^{-2} \mathrm{~s}^{-1}\right)$}

The $\mathrm{CO}_{2}$ concentration rate of soybean was significantly influenced by the different treatments (Table 1). The $\mathrm{CO}_{2}$ concentration was found to increase with crop growth in all the treatments. The results revealed that treatment $\mathrm{T}_{1}$ (application of $100 \% \mathrm{RDF}$ through $\mathrm{CF}$ ) found significantly highest $\mathrm{CO}_{2}$ rate $\left(376,382\right.$ and $391 \mu \mathrm{mol} \mathrm{CO}_{2}$ $\left.\mathrm{m}^{-2} \mathrm{~s}^{-1}\right)$ at 28, 56 and 84 DAS respectively) among the treatments, however, it was at par with treatments $\mathrm{T}_{2}$ and $\mathrm{T}_{3}$. Among the integrated nutrient source treatments $\left(\mathrm{T}_{2}\right.$ to $\left.\mathrm{T}_{5}\right)$, the treatment $\mathrm{T}_{3}$ i.e. $(50 \% \mathrm{RDN}$ through $\mathrm{CF}+50 \% \mathrm{RDN}$ through $\mathrm{VC}$ ) found maximum $\mathrm{CO}_{2}$ concentration followed by treatment $\mathrm{T}_{2}(50 \% \mathrm{RDN}$ through $\mathrm{CF}+50 \% \mathrm{RDN}$ through FYM). Such observational trends were found on all the three dates (28, 56 and $84 \mathrm{DAS})$. This might be due to the fact that the combined application of FYM and vermicompost provided adequate quantity of nutrients throughout the crop growth period and resulted in luxurious growth of crop which reflected in to more interception of light for photosynthesis, increased transpiration rate thereby more amount of $\mathrm{CO}_{2}$ accumulated in the intercellular space and maintained the leaf temperature. The results are in accordance with those reported by Lambade (2013) and Patra and Sinha (2014).

\section{Absorbed PAR ( $\left.\mu \mathrm{mol} \mathrm{m}^{-2} \mathrm{~s}^{-1}\right)$}

Absorbed photosynthetically active radiation (PAR) of soybean was influenced significantly due to different nutrient sources (Table 1). The absorbed PAR was in the range of 728 to $800 \mu \mathrm{mol} \mathrm{m}^{-2} \mathrm{~s}^{-1}$ at $28 \mathrm{DAS}$ and increased to more than $1000 \mu \mathrm{mol} \mathrm{m-2} \mathrm{s}^{-1}$ at $56 \mathrm{DAS}$, significantly decreased thereafter,being lowest at 84 DAS. Among the treatments, $\mathrm{T}_{1}$ (application of $100 \% \mathrm{RDF}$ through $\mathrm{CF}$ ) resulted in maximum absorbed PAR in comparison to all the other treatments and at all the three dates $(28,56$ and 84 DAS). However, it was at par with treatments $\mathrm{T}_{2}(50 \% \mathrm{RDN}$ through $\mathrm{CF}+50 \% \mathrm{RDN}$ through $\mathrm{VC})$ and $\mathrm{T}_{3}(50 \% \mathrm{RDN}$ through $\mathrm{CF}$ $+50 \%$ RDN through FYM). The lowest absorbed PAR was observed in treatment $\mathrm{T}_{5}$ (Table 1$)$.

\section{Stomatal conductance ( $\left.\mathrm{m} \mathrm{mol} \mathrm{m} \mathrm{m}^{-2} \mathrm{~s}^{-1}\right)$}

The stomatal conductance of soybean was significantly influenced by the different nutrient sources treatments (Table 2). Among three dates of observation, the stomatal conductance was maximum at 56 DAS ( 0.39 and $\left.0.42 \mathrm{~m} \mathrm{~mol} \mathrm{~m}^{-2} \mathrm{~s}^{-1}\right)$ under different treatments and lowest $\left(0.14\right.$ and $\left.0.17 \mathrm{~m} \mathrm{~mol} \mathrm{~m}^{-2} \mathrm{~s}^{-1}\right)$ at $84 \mathrm{DAS}$. Among the treatments the stomatal conductance was significantly highest in treatment $\mathrm{T}_{1}$ (application of $100 \% \mathrm{RDF}$ through $\mathrm{CF}$ ) and lowest in treatment $\mathrm{T}_{5}(25 \% \mathrm{RDN}$ through $\mathrm{CF}+25 \%$ through FYM $+25 \%$ through VC). At all the three dates i.e. 28,56 and $84 \mathrm{DAS}$, similar results were obtained.

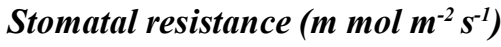

The stomatal resistance of soybean was influenced 
significantly by different treatments and with the stage of the crop (Table 2). The stomatal resistance were maximum at 84 DAS followed by at 28 DAS and lowest at 54 DAS in all the treatments. It was in reverse trend of stomatal conductance. In different treatments also the significant highest stomatal resistance was found in treatment $\mathrm{T}_{5}$ (application of $25 \% \mathrm{RDN}$ through $\mathrm{CF}+25 \% \mathrm{RDN}$ through $\mathrm{FYM}+25 \% \mathrm{RDN}$ through $\mathrm{VC}+25 \% \mathrm{RDN}$ through NC) and lowest was recorded with treatment $\mathrm{T}_{1}$ (the application $100 \%$ RDF through CF) at all the three dates of observations.

\section{Transpiration rate ( $\mathrm{m} \mathrm{mol} \mathrm{H}_{2} \mathrm{O} \mathrm{m}^{-2} \mathrm{~s}^{-1}$ )}

The transpiration rate of soybean was found to vary with crop growth stage and with treatments (Table 3). The transpiration rate was maximum (6.98 to $7.67 \mathrm{~m} \mathrm{~mol} \mathrm{H}_{2}$ $\mathrm{Om}^{-2} \mathrm{~s}^{-1}$ ) at 56 DAS in all the treatments. At 28 DAS, the transpiration rates were in the range of 3.19 to $3.52 \mathrm{~m} \mathrm{~mol}$ $\mathrm{H}_{2} \mathrm{O} \mathrm{m}^{-2} \mathrm{~s}^{-1}$, while at $84 \mathrm{DAS}$, it varied between 4.0 and $4.4 \mathrm{~m}$ $\mathrm{mol} \mathrm{H}_{2} \mathrm{O} \mathrm{m}^{-2} \mathrm{~s}^{-1}$. Among the treatments, $\mathrm{T}_{1}$ gave highest transpiration rate which was significantly higher than rest of the treatments but generally at par with treatment $\mathrm{T}_{3}(50 \%$ $\mathrm{RDN}$ through $\mathrm{CF}+50 \% \mathrm{RDN}$ through $\mathrm{VC}$ ).

\section{Leaf temperature $\left({ }^{\circ} \mathrm{C}\right)$}

Leaf temperature of soybean did not vary much and ranged between 27.8 to $30.2^{\circ} \mathrm{C}$ across the treatments over the crop growth period. The differences in leaf temperature due to treatments were non - significant at all the three dates of observations. However, leaf temperature was higher in treatment $\mathrm{T}_{5}$ at $56 \mathrm{DAS}$.

\section{CONCLUSION}

The physiological parameters of soybean viz., photosynthetic rate, $\mathrm{CO}_{2}$ concentration, stomatal conductance, transpiration rate and absorbed photosynthetically active radiation were significantly highest in $100 \%$ RDF and at par with $50 \%$ RDN through
$\mathrm{CF}+50 \% \mathrm{RDN}$ through $\mathrm{VC}$ and $50 \% \mathrm{RDN}$ through $\mathrm{CF}+$ $50 \%$ RDN through FYM and significantly lowest in treatments having nutrient application through neem cake (NC).

\section{REFERENCES}

Allen, L.H., Pan, D., Boote, K.J., Pickering, N.B and Jones, J.W. (2003). Carbon dioxide and temperature effects on evapotranspiration and water use efficiency of soybean. Agron. J., 95:1071-1081.

Allen, L.H., Valle, R.R., Jones, J.W and Jones, P.H. (1998). Soybean leaf water potential responses to carbon dioxide and drought. Agron. J., 90:375-383.

Bhagat, K.P., Bal, S.K., Singh, Y., Potekar, S., Saha, S., Ratnakumar, P., Wakchaure, G.C. and Minhas, P.S. (2017). Effect of reduced PAR on growth and photosynthetic efficiency of soybean genotypes. J. Agrometeorol., 19(1):1-9.

Lambade, B.M. (2013). Effect of different organic inputs on soybean+pigeonpea-summer groundnut cropping system under irrigated condition. Ph.D. thesis submitted to Mahatma Phule Krishi Vidyapeeth, Rahuri (M.S.) India.

Patra, P.S. and Sinha, A.C. (2014). Growth, net photosynthesis and seed yield of groundnut (Arachis hypogaea L.) as influenced by organic sources of nutrient. Legume Res., 37(5):520.

Rodrigues-Das-Dores, Rg and Casali, Vwd. (2007). "Medicinal and Aromatic Plants: quality control of herbal medicines". Ponte Nova: D\&M. 160p.

Singh, Harpreet and Hundal, S.S. (2004). Effect of sowing dates and differential water application on microclimate and yield of soybean (Glycine Max L.). J. Agrometeorol., 6(special issue):47-51. 